\title{
New Technological Knowledge of the Rotary Turning Tool
}

Karol Vasilko ${ }^{1}$, Jozef Pilc ${ }^{2}$

${ }^{1}$ Faculty of Manufacturing Technologies Technical University of Košice, 08001 Prešov, Bayerova 1, SR, karol.vasilko@tuke.sk

${ }^{2}$ University of Žilina, Faculty of Technological Engineering, 01026 Žilina, Univerzitná 1, jozef.pilc@ @stroj.uniza.sk

In the previous paper [12], a design of location and construction of a rotating turning tool has been documented. Sporadically, this tool has appeared in literature [1], [2], [3], [4] in different applications. So far its operational characteristics, mainly its considerable influence on machined surface quality, exceptional durability and possibility to be used to turn hard machinable materials have not been appreciated. Some of its priorities are verified in the paper.

Keywords: rotating tool, tool durability, machined surface quality

\section{Rereferences}

[1] CHEN, P.: High-Performance Machining of SiC Whisker-Reinforced Aluminium Composits by Self-Propelled Rotary Tools. Annals of the CIRP Vol.41/1/1992, p. 59-6l'

[2] SHAW, M. S., SMITH, P., COOK, N.: The rotary cutting tool. Trans. of ASME, Vol. 74, p. 1065-1076

[3] VENUVINOD, Pk., REDDY, P. N.: Some Studies on Cutting with Self Propelled Rotary Tools. ASME, 81WA/Prod-16

[4] BOBROV, V, F., JERISALIMSIJ, D, E.: Kinematika rezanij čašečnymi rezcami. Vestnik mašinostrojenija, Nr. 6, 1969, s. 17-19

[5] VASILKO, K., MÁDL, J.: Teorie obrábění 2. díl. Univerzita J.E.Purkyně, Ústí nad Labem: 2012, 526 s., ISBN 978-80-7414-460-8

[6] VASILKO, K.- PILC, J.: Klzné uloženie rotujúceho sústružníckeho noža. Patent SR č. 211 831, 21.3.1980

[7] KALPAKJIAN, S.: Manufacturing engineering and technology. New York: Addison Westley Publishing Company, 1989, pp 1999, ISBN 0-201-12849-7

[8] IVANTIŠIN, J.: Hydraulické a pneumatické mechanizmy. Bratislava: ALFA,: 1982, $220 \mathrm{~s}$.

[9] KUNDRÁK, J.: Alternative machining procedures of hardened steels. Manufacturing Technology, December 2011, Vol.11, No.11, pp.32-39

[10] MAKEDONSKI, A., OHRIDSKI, K,: Unconvential machining method for enhancing the durability of tools and strength of the specimens bonded. In: Manufacturing Technology, December 2011, Vol. 11, No.11

[11] HOLEŠOVSKÝ, F., NÁPRSTKOVÁ, N., NOVÁK, M.: GISC for grinding process optimalization. In: Manufacturing Technology, 2012, Vol.12, Nr. 12

[12] PILC, J., VASILKO, K.: Development and applications of a rotating turning tool. Manufacturing Technology, JUNE 2013, Vol. 13, No. 2, pp. 226-231 